\title{
Hydrological system time lag responses to meteorological shifts
}

\section{Defasagem temporal de resposta do sistema hidrológico sob mudanças meteorológicas}

\author{
Davi de Carvalho Diniz Melo ${ }^{1}$ and Edson Wendland ${ }^{1}$ \\ ${ }^{1}$ Escola de Engenharia de São Carlos, Universidade de São Paulo, São Carlos, SP, Brazil \\ E-mails: engdavi@usp.br (DCDM), ew@sc.usp.br (EW)
}

Received: June 20, 2016 - Revised: July 24, 2016 - Accepted: July 25, 2016

\begin{abstract}
Hydrological system's sensibility and resilience to dry periods are crucial for estimating the potential impacts of droughts. Quantifying response times (RT) of this system's components relative to droughts allows one to develop a predictive understanding of future impacts. In this context, this study proposes the use of non-parametric statistical methods to estimate RT between meteorological shifts, given by the Standardized Precipitation Index (SPI), and the respective changes in the hydrological system, measured by river discharge (Q) and reservoir storage time series. Change point (CP) analyses were applied to time series of (i) SPI and accumulated storage relative to 32 reservoirs within the Paraná basin; and (ii) SPI, Q and reservoir storage relative to Furnas hydroelectric power plant. Based on the responses from CP analyses, RT in case (i) varied from $0-6$ months, whereas, in case (ii), results indicate that significant changes in Q occurred in the same month of changes in rainfall. Results also suggest a minor role of anthropogenic factors (dam operation) compared to natural forcing in reservoir depletion during the 2014 drought than that in 2000/2001. This study reinforces the importance of an optimized reservoir management, considering the balance between anthropogenic and natural forcing as a strategy to combat droughts impacts.
\end{abstract}

Keywords: Meteorological drought; SPI; Change point analysis; Time series.

\section{RESUMO}

A sensibilidade de um sistema hidrológico e sua capacidade de recuperação após períodos de estiagem são questões determinantes para estimar o impacto potencial de secas. A quantificação dos tempos de resposta (TR) de componentes desse sistema em relação às secas possibilita antecipar futuros impactos. Neste contexto, o presente trabalho propõe a utilização de métodos estatísticos não-paramétricos para estimar TR entre mudanças meteorológicas, medidas por meio do índice de precipitação padronizado (SPI), e respectivas alterações no sistema hidrológico, medidas por meio de séries de vazão (Q) e de armazenamento em reservatórios. Para o desenvolvimento deste trabalho, foram estimados os pontos de mudanças das séries temporais de (i) SPI e volume de armazenamento mensal equivalente de 32 reservatórios da bacia do Rio Paraná; e de (ii) SPI, vazão e volume de armazenamento no reservatório da usina hidrelétrica de Furnas. Com base nas respostas dos métodos empregados, o TR para o caso (i) varia de 0 a 6 meses, enquanto que, para o caso (ii), os resultados indicam que mudanças significativas na vazão devido a mudanças na precipitação ocorrem em menos de 1 mês. Os resultados também mostram que os fatores antropogênicos (operação dos reservatórios) contribuíram menos para depleção dos reservatórios na seca de 2014 do que em 2000/2001. Este trabalho reforça a importância da otimização na operação de reservatórios visando o melhor equilíbrio entre fatores naturais e antropogênicos como estratégia de combate aos efeitos das secas.

Palavras-chave: Seca meteorológica; SPI; Ponto de mudança; Séries temporais. 


\section{INTRODUCTION}

Climate extremes, commonly reflected in the hydrological system as natural disasters, often bring negative impacts on society. Natural disasters, such as droughts, can cause major impacts on water supply and electricity generation. Between 1970 and 2012 , droughts were responsible for $\sim 1 / 3$ of disaster-related deaths and $\sim$ US $\$ 200$ billion of economic losses globally (WMO, 2014). In Brazil, two major droughts affected millions of people in the current millennium by jeopardizing (i) hydroelectricity generation in the early 2000s, which caused the implementation of energy-rationing programs and blackouts, and (ii) potable water supply for $\sim 130$ cities in the southeast region (ROSA; LOMARDO, 2004; LOBEL et al., 2014).

Droughts can be classified according to the following types: meteorological (abnormal negative precipitation anomaly), agricultural (abnormal low soil moisture), hydrological (reduced streamflow, low water table levels, etc) and socio-economic (failure to supply the demand of economic goods, such as potable water, food grains, hydroelectric generation, etc) (WILHITE; GLANTZ, 1985).

Although this distinction is often neglected in droughtrelated studies, it is necessary for characterizing the impacts on different components of the hydrological system. Ignoring this distinction may lead to some problems, such as propagating misleading information. Wilhite and Glantz (1985) revised some cases worldwide in which droughts were estimated to have had a certain duration but, as meteorologists analysed the precipitation in the region, initial estimates were proved to be inaccurate. Such divergences were caused because a clear distinction between types of droughts was lacking.

Several studies focused on understanding how the meteorological drought propagates to socio-economic drought (VAN LOON; VAN HUIJGEVOORT; VAN LANEN, 2012; BARKER et al., 2015; WANG et al., 2016; FIORILLO; GUADAGNO, 2010; TIGKAS; VANGELIS; TSAKIRIS, 2012). Quantifying linkages between types of droughts requires continuous monitoring of drought indicators and is critical for drought preparedness. Although meteorological droughts cannot be avoided, the society can take measures to mitigate hydrological and agricultural droughts, for example. As reported by Barker et al. (2015), hydrological responses to meteorological droughts occurs after a certain time interval, that is, hydrological and meteorological droughts are lagged events.

As previously mentioned, meteorological drought occurrence is, essentially, human independent; but its effect on the hydrological system depends on the actions taken by society. In this definition we are not considering man induced climate changes, since this issue is out of the scope of our analysis. Additionally, it may be utopic to assume that the end of a meteorological drought is instantaneously followed by the end of a hydrological drought. Leblanc et al. (2009) reported a continuous decline of groundwater storage even 6 years after the onset of the meteorological drought and a persistence of the hydrological drought although rainfall was close to the historic annual average in the sixth year.

Previous estimates of the time lag between the onset of meteorological droughts and the impacts on the hydrological system ranged from few months (BARKER et al., 2015; VICENTE-SERRANO; LÓPEZ-MORENO, 2005) to few years (LEBLANC et al., 2009; VAN DIJK et al., 2013; BARKER et al., 2015). Quantifying such time lags is crucial to anticipate the associated impacts and implement mitigation measures to minimize such impacts.

However, none of the previous studies assessed the proper method to calculate the time lag between meteorological shifts and hydrological responses. Adopted approaches are widely different amongst studies. Van Dijk et al. (2013) compared timing of occurrence of minimum values of average precipitation anomalies and total water storage. Vicente-Serrano and LópezMoreno (2005) calculated correlation coefficients (CC) between reservoir storage and the Standardized Precipitation Index (SPI) at different time scales and assuming that the time lag is given as the time scale with higher CC.

In this context, the objective of this study is to quantify the time lag between meteorological shifts, measured by means of SPI, and the hydrological system response in the Paraná basin. To achieve this goal, non-parametric statistics-based approaches (change-point analysis) were applied to rainfall, river discharge and reservoir storage time series. This analysis was carried out considering two cases. First, the time lag between changes in SPI and water storage of 32 reservoirs in the Paraná basin was evaluated. Second, a reservoir within the Paraná basin was selected as a case study with the objective of evaluating the response time lag in river discharge as well.

To the authors' knowledge, the use of change-point analysis with the proposed end is unprecedented and unique; furthermore, it can provide trustful and valuable insights for water resources planning in the context of droughts preparedness.

\section{MATERIAL AND METHODS}

\section{Study area}

The reservoirs within the Paraná basin $(\mathrm{PB})\left(\sim 880,000 \mathrm{~km}^{2}\right)$ were selected as a case study due to the importance of this basin for the country (Figure 1). The PB, southeast Brazil, is the most populated basin in Brazil, accounting for $\sim 55 \%$ of national Gross Domestic Product (GDP) in 2012 and $\sim 65 \%$ of national population; it produces $\sim 60 \%$ of the hydroelectricity in Brazil and provides $\sim 25 \mathrm{~km}^{3} /$ yr of surface water for several uses (ANA, 2010; IBGE, 2014).

The time lags between meteorological forcing and hydrological responses were evaluated considering the 32 reservoirs as an equivalent system and a typical case within the Paraná basin. Reservoir storage of the equivalent system (RESS) was obtained by accumulating monthly storage data of the selected reservoirs. To calculate SPI, the rainfall in the contributing basins of the 32 reservoirs was averaged. The reservoir of Furnas hydroelectric power plant (HEP) (Figure 1) was selected as a detailed case study in the PB because the monthly storage variation is similar to that of the equivalent system. Further information about the reservoirs is shown in Table 1. 


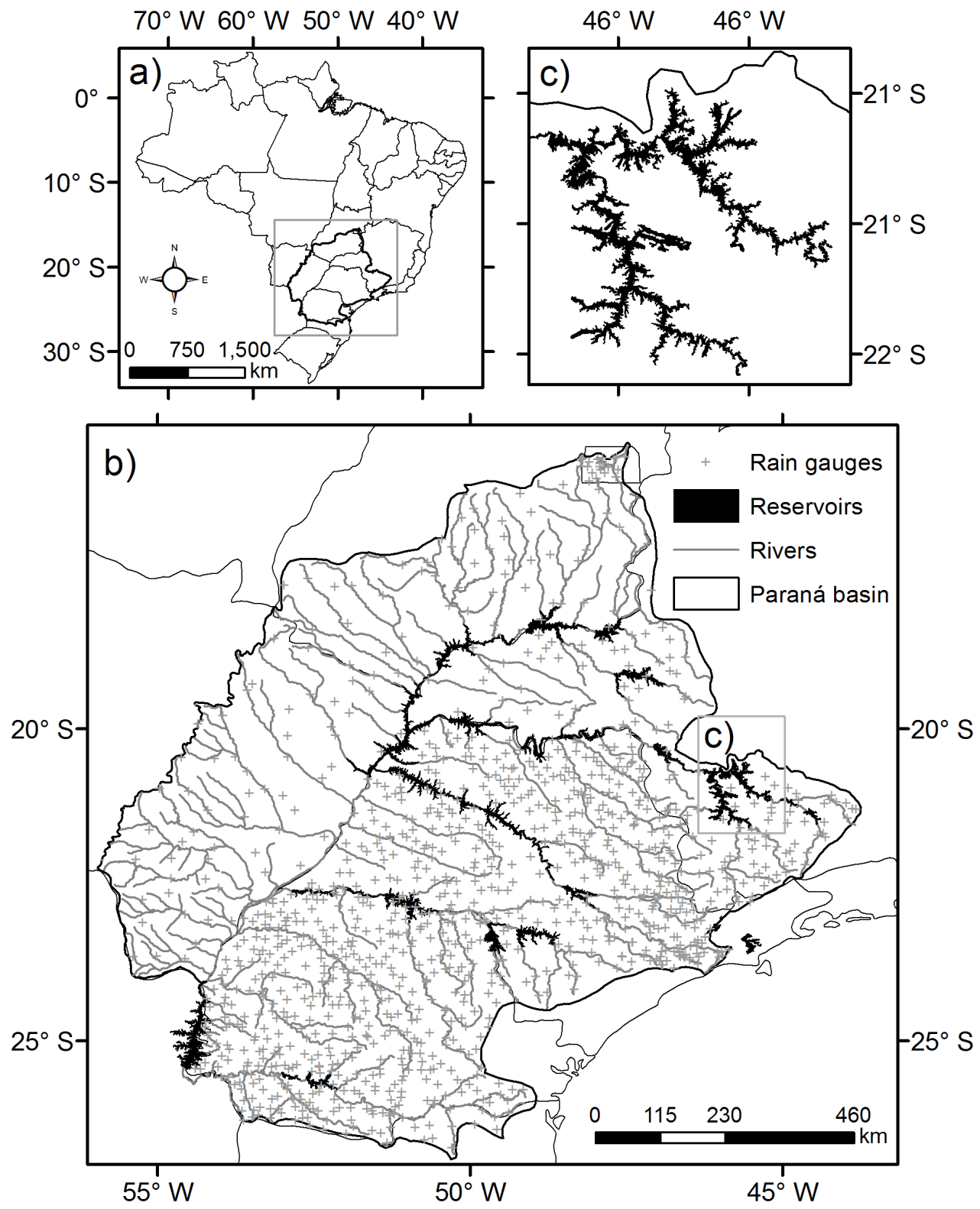

Figure 1. Study area: the Paraná basin in the national context (a); 32 reservoirs composing the equivalent system (b); and Furnas reservoir, selected as a detailed case study (c).

\section{Rainfall and reservoir data}

The rainfall data used in this study combines ground-based data $\left(\mathrm{P}_{\text {obs }}\right)(1995-2013)$ and satellite-based estimates $\left(\mathrm{P}_{\text {sat }}\right)(2013-2015)$. $\mathrm{P}_{\text {obs }}$ consists of a gridded product constructed by Xavier, King and Scanlon (2015) using 1127 rain gauges in the Paraná basin. $\mathrm{P}_{\text {sat }}$ consists of rainfall estimates from the Tropical Rainfall Measuring Mission (TRMM) Multi-satellite Precipitation Analysis (TMPA), product 3B43 version 7. TMPA 3B43 merges daily estimates from 3B42 product with gauge data to create a single rain product (Huffman et al., 2007). TMPA data are obtained by combining measurements of the following instruments aboard on TRMM satellites: Precipitation Radar, Microwave imager and Visible
Infrared Scanner. Eventual remaining gaps in the estimates were filled using infrared data from geosynchronous satellites across the tropics (NASA, 2011). Both $\mathrm{P}_{\text {obs }}$ and $\mathrm{P}_{\text {sat }}$ are available in a $0.25^{\circ} \times 0.25^{\circ}$ horizontal grid.

Reservoir storage data from 32 reservoirs (Table 1) and inflow/outflow records from Furnas HEP were downloaded from the Brazilian Water Agency (ANA - Agência Nacional de Águas) web site (http:/ / sar.ana.gov.br/MedicaoSIN), considering the period Jan 1995 - Jun 2015. The data is available at daily scale. Because SPI is given as monthly values, reservoir daily data were averaged to obtain monthly time series. Seasonal signal from the discharge data was removed prior to the change point analysis by subtracting monthly data by the monthly means $\left(\bar{Q}_{J a n}, \bar{Q}_{F e b}, \ldots, \bar{Q}_{D e c}\right)$. 
Table 1. General information about the reservoirs considered in this study.

\begin{tabular}{|c|c|c|c|c|c|}
\hline Reservoir & Perimeter $(\mathrm{km})$ & Lake area $\left(\mathrm{km}^{2}\right)$ & Latitude & Longitude & Active Vol. $\left(\mathrm{hm}^{3}\right)$ \\
\hline Água Vermelha & 973 & 592 & $-19.86^{\circ}$ & $-50.34^{\circ}$ & 11025 \\
\hline Bariri & 122 & 45 & $-22.15^{\circ}$ & $-48.75^{\circ}$ & 607 \\
\hline Barra Bonita & 544 & 268 & $-22.64^{\circ}$ & $-48.27^{\circ}$ & 3622 \\
\hline Cachoeira Dourada & 120 & 59 & $-18.50^{\circ}$ & $-49.49^{\circ}$ & 222 \\
\hline Camargos & 381 & 60 & $-21.33^{\circ}$ & $-44.62^{\circ}$ & 672 \\
\hline Capivara & 1339 & 564 & $-22.80^{\circ}$ & $-51.04^{\circ}$ & 5724 \\
\hline Chavantes & 1029 & 363 & $-23.13^{\circ}$ & $-49.73^{\circ}$ & 3041 \\
\hline Emboracação & 980 & 382 & $-18.44^{\circ}$ & $-47.99^{\circ}$ & 13056 \\
\hline Funil & 188 & 31 & $-21.16^{\circ}$ & $-44.90^{\circ}$ & 258 \\
\hline Furnas & 3838 & 1203 & $-20.96^{\circ}$ & $-45.85^{\circ}$ & 17217 \\
\hline Ibitinga & 300 & 92 & $-21.76^{\circ}$ & $-48.99^{\circ}$ & 56 \\
\hline Ilha Solteira & 2017 & 1165 & $-20.38^{\circ}$ & $-51.36^{\circ}$ & 5516 \\
\hline Itaipu & 2489 & 1338 & $-25.41^{\circ}$ & $-54.59^{\circ}$ & 19000 \\
\hline Itumbiara & 1755 & 702 & $-18.41^{\circ}$ & $-49.10^{\circ}$ & 12454 \\
\hline Jaguara & 84 & 33 & $-20.02^{\circ}$ & $-47.43^{\circ}$ & 100 \\
\hline Jaguari & 324 & 38 & $-23.19^{\circ}$ & $-46.08^{\circ}$ & 793 \\
\hline Jupiá & 362 & 297 & $-20.78^{\circ}$ & $-51.63^{\circ}$ & 903 \\
\hline Jurumirim & 1003 & 414 & $-23.21^{\circ}$ & $-49.23^{\circ}$ & 3165 \\
\hline Marechal M. de Moraes & 784 & 233 & $-20.42^{\circ}$ & $-46.85^{\circ}$ & 2500 \\
\hline Marimbondo & 697 & 363 & $-20.31^{\circ}$ & $-49.19^{\circ}$ & 5260 \\
\hline Nova Avanhandava & 423 & 195 & $-21.12^{\circ}$ & $-50.20^{\circ}$ & 433 \\
\hline Nova Ponte & 1624 & 406 & $-19.16^{\circ}$ & $-47.36^{\circ}$ & 10380 \\
\hline Paraibuna & 922 & 132 & $-23.37^{\circ}$ & $-45.66^{\circ}$ & 2636 \\
\hline Porto Colômbia & 251 & 128 & $-20.13^{\circ}$ & $-48.57^{\circ}$ & 1525 \\
\hline Promissão & 986 & 519 & $-21.30^{\circ}$ & $-49.78^{\circ}$ & 2479 \\
\hline Rosana & 313 & 196 & $-22.59^{\circ}$ & $-52.86^{\circ}$ & 408 \\
\hline Salto Osório & 201 & 47 & $-25.53^{\circ}$ & $-53.01^{\circ}$ & 403 \\
\hline Salto Santiago & 701 & 192 & $-25.61^{\circ}$ & $-52.62^{\circ}$ & 4094 \\
\hline São Simão & 1085 & 609 & $-19.02^{\circ}$ & $-50.50^{\circ}$ & 5540 \\
\hline Taquaraçu & 234 & 85 & $-22.62^{\circ}$ & $-51.78^{\circ}$ & 135 \\
\hline Três Irmãos & 1220 & 651 & $-20.67^{\circ}$ & $-51.30^{\circ}$ & 3450 \\
\hline Volta Grande & 339 & 182 & $-20.09^{\circ}$ & $-48.04^{\circ}$ & 2244 \\
\hline
\end{tabular}

\section{Meteorological drought index}

The Standardized Precipitation Index (SPI) is a traditional choice for characterizing meteorological droughts as it provides information concerning positive/negative anomalies in rainfall, at different time scales (e. g., VICENTE-SERRANO; LOPEZMORENO, 2005; FIORILLO; GUADAGNO, 2009) based on historical records. To calculate SPI, rainfall records are fit to a probability function, usually Gamma, and the cumulative probability of rainfall occurrence over an area is obtained (MCKEE; DOESKEN; KLEIST, 1993; TEODORO et al., 2015). In this study, SPI was obtained at a 12-month scale (SPI-12).

\section{Change-point analysis}

There are several approaches available for detecting change point (CP) in time series (PETTITT, 1979; SHARIFZADEH; AZMOODEH; SHAHABI, 2005; RADZIEJEWSKI; BARDOSSY; KUNDZEWICZ, 2000; LAVIELLE, 1999; SHI et al., 2016). However, each approach may result in different results depending on the employed method. A time series may contain change in mean, variance, regression or time-dependency. Here, only the changes in the mean were considered. In this study, various non-parametric methods were used.

One of the selected approaches for such purpose is that proposed by Pettitt (1979), previously used to determine change points in streamflow and sediment discharge time series (GAO et al., 2011). This method is based on the Mann-Whitney test but the calculated statistic $\left(U_{t, T}\right)$ is given by:

$U_{t, T}=\sum_{i=1}^{t} \sum_{j=i+1}^{T} \operatorname{sgn}\left(X_{i}-X_{j}\right)$

where $X_{1}, X_{2}, \ldots, X_{T}$ are the values in the time series $\mathrm{X}$, $\operatorname{sgn}(x)=1$ if $x>0,0$ if $x=0$ and -1 if $x<0$ (PETTITT, 1979). After computing the statistic $U_{t, T}$ for all $\mathrm{t}=1,2, \ldots$ T, the test statistic $K_{T}$ is determined:

$$
K_{T}=\max _{1 \leq t<T}\left|U_{t, T}\right|
$$

The significance probability associated with $K_{T}$ is, thus, obtained as:

$$
p_{o} \cong 2 \exp \left(\frac{-6 K_{T}^{2}}{T^{2}+T^{3}}\right)
$$


The null hypothesis that $X_{i}$ and $X_{j}$ come from different samples, i.e. no change point detected, is rejected if $p_{o} \leq p_{\text {lim }}$. Here we adopted a significance level of 0.01 , hence, $p_{\text {lim }}=99 \%$.

The second approach is similar to that applied by Gocic and Trajkovic (2013) to detect changes in meteorological variables; it combines cumulative sums (CUSUM) with data resampling using bootstrap method (EFRON, 1979). Our analysis is based on 1000 bootstrap samples. Given a sample data vector $\mathrm{X}=\left\{X_{1}, X_{2}, \ldots, X_{T}\right\}$, where $\mathrm{T}$ is the vector length, the cumulative sums $S_{0}, S_{1}, \ldots, S_{T}$ are obtained by $S_{i}=S_{i-1}+\left(X_{i}-\bar{x}\right)$, with $i=1,2, \ldots, T$ and $\bar{x}=$ average of $\mathrm{X}$.

Bootstrap analysis is applied to determine the confidence level. Given $S_{\max }$ (Equation 4) and $S_{\min }$ (Equation 5) the magnitude of change $\left(S_{\text {diff }}\right)$ is calculated by Equation 6 .

$$
\begin{aligned}
& S_{\max }=\max _{i=1,2, \ldots, T} S_{i} \\
& S_{\min }=\min _{i=1,2, \ldots, T} S_{i} \\
& S_{\text {diff }}=S_{\max }-S_{\text {min }}
\end{aligned}
$$

Further, the original vector $\mathrm{X}$ is randomly reordered, generating a bootstrap sample $x_{1}^{0}, x_{2}^{0}, \ldots, x_{T}^{0}$, from which the bootstrap CUSUM $\left(S_{1}^{0}, S_{2}^{0}, \ldots, S_{T}^{0}\right)$ will be obtained. Bootstrap CUSUM $S_{\max }^{0}$ and $S_{\min }^{0}$ are calculated to determine the number of bootstraps (N) for which $S_{\text {diff }}^{0}<S_{\text {diff }}$. This process is repeated $T$ times and the confidence level at which a CP occurred is given as:

$$
\text { confidencelevel }=100 \frac{N}{T} \%
$$

Finally, a R package (CPM) for multiple change point analysis of non-parametric time series was used (ROSS, 2015). Change point detection with CPM package is achieved by "evaluating a two-sample test statistic at every possible split point” (ROSS, 2015). The selected tests (Mann-Whitney - MW, Mood, Lepage - LP and
Kolmogorov-Smirnov - KS) used in this study are described in Ross, Tasoulis and Adams (2011) and Ross and Adams (2012).

Besides the test statistics used by CPM, the user must set two parameters: $\mathrm{ARL}_{0}$ and 'startup'. $\mathrm{ARL}_{0}$ is a parameter representing the average number of observations before the occurrence of a false positive, considering that the sequence does not undergo a change (Ross, 2015). ARL 0 can assume the following values: 370 , $500,600, \ldots, 1000,2000, \ldots, 10000,20000, \ldots, 50000$. 'startup' defines the number of observations after which the algorithm will begin to look for change points (Ross, 2015). In this study, the following values were used: $\mathrm{ARL}_{0}=1000$ and 'startup' $=40$.

\section{RESULTS AND DISCUSSIONS}

\section{Equivalent system}

The detected changes in SPI and RESS series varied depending on the method used (Table 2). In Figure 2, the change points (CPs) detected by individual methods (dashed lines, PTT - Pettitt, CSBT - CUSUM+Bootstrap, ITR - individual tests from R package) were differentiated from those identified by multiple methods (solid lines). In this second case, CPs detected by all four tests in 'CPM' (MW, Mood, LP and KS) were distinguished from those detected by at least two of the three adopted approaches (P'T', CSBT, CPM).

Not all the changes in SPI resulted in changes in RESS (e.g., Nov/2006, Oct/2007, etc). The horizontal bar in Figure 2 shows the CPs relative to SPI (upper) and RESS (bottom) selected for analysis. In this bar, months are specified as numbers: Jan (1), Feb (2), .., Dec (12).

The change point analysis indicates that a change in SPI between March (3) and July (7) 1999 caused the depletion of the equivalent system starting between July (7) and September (9) 1999. This indicates that the time lag between the meteorological shift and the hydrological response (significant decline) in RESS was

\begin{tabular}{|c|c|c|c|c|c|c|c|c|c|c|c|c|}
\hline & \multicolumn{2}{|c|}{ CSBT } & \multicolumn{2}{|c|}{ PTT } & \multicolumn{2}{|c|}{ MW } & \multicolumn{2}{|c|}{ Mood } & \multicolumn{2}{|c|}{ LP } & \multicolumn{2}{|c|}{ KS } \\
\hline \multirow{10}{*}{ SPI } & $23(1)$ & Nov 1996 & $13(0.95)$ & Jan 1996 & 22 & Oct 1996 & 57 & Sep 1999 & 23 & Nov 1996 & 23 & Nov 1996 \\
\hline & $55(1)$ & Jul 1999 & $23(1)$ & Nov 1996 & 51 & Mar 1999 & 73 & Jan 2001 & 55 & Jul 1999 & 51 & Mar 1999 \\
\hline & $69(0.99)$ & Sep 2000 & $55(0.99)$ & Jul 1999 & 144 & Dec 2006 & 144 & Dec 2006 & 68 & Aug 2000 & 68 & Aug 2000 \\
\hline & $143(1)$ & Nov 2006 & $69(0.99)$ & Sep 2000 & 176 & Aug 2009 & & & 144 & Dec 2006 & 176 & Aug 2009 \\
\hline & $154(0.99)$ & Oct 2007 & $113(1)$ & May 2004 & 188 & Aug 2010 & & & 178 & Oct 2009 & 187 & Jul 2010 \\
\hline & $176(1)$ & Aug 2009 & $176(1)$ & Aug 2009 & 229 & Jan 2014 & & & 229 & Jan 2014 & 229 & Jan 2014 \\
\hline & $188(0.99)$ & Aug 2010 & $188(1)$ & Aug 2010 & & & & & & & & \\
\hline & $205(0.99)$ & Jan 2012 & $194(0.98)$ & Feb 2011 & & & & & & & & \\
\hline & $229(0.99)$ & Jan 2014 & $205(0.97)$ & Jan 2012 & & & & & & & & \\
\hline & $240(0.99)$ & Dec 2014 & & & & & & & & & & \\
\hline \multirow{6}{*}{ RESS } & $55(1)$ & Jul 1999 & $44(0.99)$ & Aug 1998 & 44 & Aug 1998 & 56 & Aug 1999 & 56 & Aug 1999 & 56 & Aug 1999 \\
\hline & $69(0.97)$ & Sep 1999 & $57(0.99)$ & Sep 1999 & 56 & Aug 1999 & 84 & Dec 2001 & 85 & Jan 2002 & 84 & Dec 2001 \\
\hline & 85 (1) & Jan 2002 & $85(0.99)$ & Jan 2002 & 84 & Dec 2001 & 213 & Sep 2012 & 213 & Sep 2012 & 111 & Mar 2004 \\
\hline & $110(1)$ & Feb 2004 & $110(1)$ & Feb 2004 & 110 & Feb 2004 & & & & & 211 & Jul 2012 \\
\hline & $212(1)$ & Aug 2012 & $211(0.99)$ & Jul 2012 & 211 & Jul 2012 & & & & & & \\
\hline & $229(1)$ & Jan 2014 & $229(0.99)$ & Jan 2014 & & & & & & & & \\
\hline
\end{tabular}
0-6 months. Considering the onset of the meteorological drought

Table 2. Position of detected change point (CP) and associated probability (CSBT and PTT) by individual methods in RESS (Reservoir Storage of the equivalent System) and SPI (Standardized Precipitation Index) time series.

CSBT = Cumulative Sums + Bootstrap; PTT = Pettitt; MW = Mann-Whiteny; LP = Lepage; KS = Kolmogorov-Smirnov. 

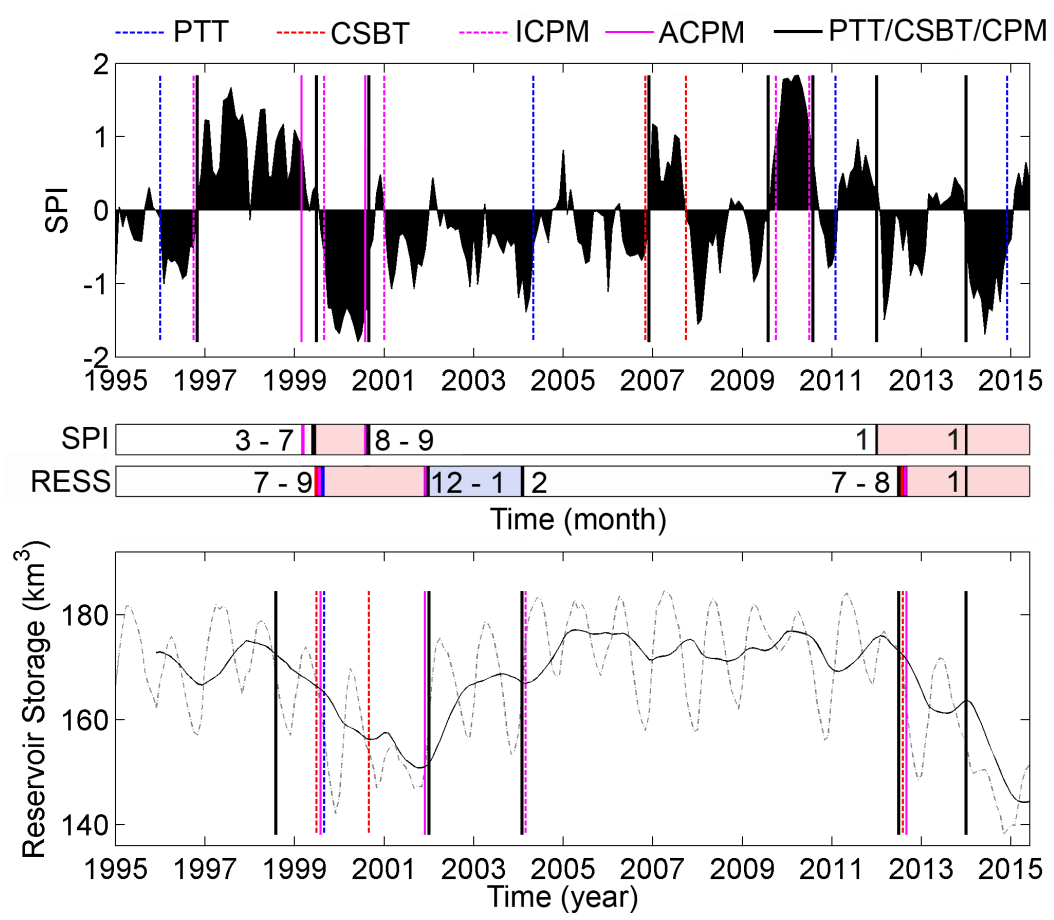

Figure 2. Detected change points (CPs) in SPI and reservoir storage of the equivalent system (RESS). The CPs selected for analysis are featured in the horizontal bar in the center; it shows the months when the changes occurred (Jan-1, Feb-2, ..., Dec-12). Dashed lines represent the CPs from Pettitt (PTT) and CUSUM+Bootstrap (CSBT) methods; and individual tests from CPM package (ICPM). Solid lines represent the CPs detected by all methods in CPM package (ACPM) or at least two out of the three used approaches (PT', CSBT or CPM).

in Jul(7) 1999, it persisted for 13-14 months (until Aug-Sep 2000) (pink bar in SPI horizontal bar). The associated consequence to RESS was the continuous decline for $\sim 15$ months (pink bar in RESS horizontal bar).

RESS complete recovery (early 2002) was independent of the onset of a wet period (Figure 2). In fact, SPI was mostly negative during the RESS recovery period (Jan/2002 - Feb/2004), indicating that such recovery is related to operational factors, i.e., outflow control. By reducing the outflow, there is a positive balance in the reservoir storage change and that leads to a reduction in hydroelectric generation (HEG). This hypothesis is supported by HEG historical data for the region (Figure 3). According to SPI, the driest period occurred in the early 2000s ( 1999-2000) but only in 2001 that a reduction in HEG occurred along with the demand. According to Figures 2 and 3, only after RESS reached its maximum capacity in 2005 the HEG resumed the expected growing that would have followed after 2000 without the drought, i.e., electric generation in 2005 was substantially greater than the previous years since the onset of the early 2000s drought.

The second major change towards the second drought of the analyzed period is detected before the beginning of the 2012/2013 water year (WY). The PTT and CSBT methods detected a CP in Jan(1) 2012 (solid black line, Figure 2) that might explain the decline in RESS that occurred between July(7) and $\operatorname{Aug}(8)$ 2012, indicating that the time lag between the meteorological shift and the hydrological response (significant decline in RESS) was 6-7 months. A second drop in both SPI and RESS occurred in $\operatorname{Jan}(1)$ 2014. The unanimity related to the position of the CP

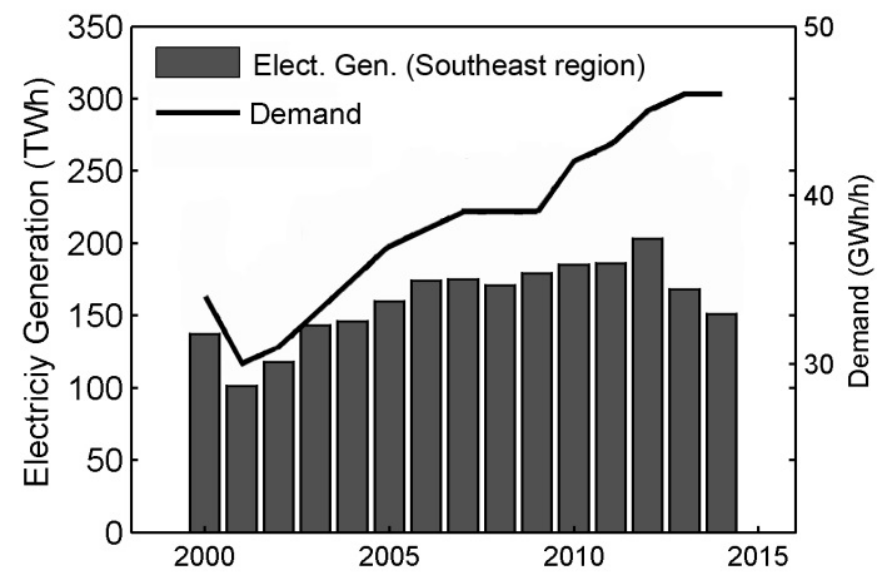

Figure 3. Electric demand and generation by 13 hydroelectric power plants in southeast and mid-west Brazil from 2000 to 2014. Source: ONS (2015).

in both SPI and RESS in Jan 2014 poses strong evidence that the response time lag of RESS to SPI decreased compared to the previous drought.

The comparison of the values reported here and in previous studies found in the literature reveals a relatively fast response of the hydrologic system in the Paraná basin. For example, VicenteSerrano and López-Moreno (2005) analyzed reservoir storage 
responses and SPI at different time scales in Spain and found time lag responses varying from 7 to 10 months.

\section{Case study: Furnas reservoir}

A detailed analysis is performed only for the Furnas reservoir (FR), which was selected as a representative case within the Paraná basin. The change points (CPs) detected in the time series of SPI, inflow anomaly $\left(Q_{\text {anomaly }}\right)$ and reservoir storage of Furnas HEP are show in Table 3.

A moderate to severe wet period $(1 \leq S P I<2)$ occurred in the WY 1996/1997, ending in Dec(12) 1997 with SPI 0 (Figure 4). The transition from that wet year to a period with rainfall ranging around the long term average reflected a change in the mean inflow (Q) to Furnas reservoir (FR) in the same month (Figure 4), i.e., a time lag of less than 1 month. Such time interval is similar, although slightly shorter, to previous values reported by Vicente-Serrano and López-Moreno (2005) and Barker et al. (2015). Both studies concluded that hydrological droughts, measured by river discharge anomalies, occurred 1-3 months after the onset of a meteorological drought.

As a result of the decrease in Q, a drop in FR levels was observed $\sim 7$ months later as a change point was detected between Jun and Aug 1998. Similar results were reported by Szalai, Szinell and Zoboki (2000) and Vicente-Serrano and López-Moreno (2005); both studies found time lag responses between SPI and reservoir storage change ranging from 7 to 10 months. Although no significant changes were observed in SPI or Q between late 1997 and early 2000s, FR storage continued to decline, with another change point in Jul(7) 2000 (Figure 4).

The early 2000s drought that led to the 2001 energy crisis in Brazil was characterized by moderate to severe dry conditions $(-2<S P I \leq-I)$ in the contributing basin of FR. CP analysis indicates the onset of a $\sim 1$ year-long (pink bar in SPI horizontal bar) meteorological drought in Jan 2001, resulting in low Q for 6-8 months (pink bar in Q bar). Regardless of the CP analysis, the impacts of such rainfall negative anomaly can also be noticed by the low peak of Q in the rainy season (Dec 2000-Feb 2001) (Figure 5), which resulted in the low reservoir levels during the same months.

Recovery of FR (blue bar in RS) began 0-3 months (Dec 2001 - Feb 2002) after rainfall returned to normality (SPI $\geq-1$ ) (Sep - Dec 2001) (Figure 4) although no substantial increase of $\mathrm{Q}$ was observed. CP analysis indicates that a complete recovery of FR occurred after 2 year (early 2002 to Feb 2004).

Prior to the 2014 drought, reservoir storage began to decline between May(5) and August(8) 2012. Similarly to the previous drought, such decline occurred although no significant decrease in rainfall and $\mathrm{Q}$ was detected. Additionally, the increasing demand

Table 3. Positin of detected change point (CP) and associated probability (CSBT and PTT) by individual methods in the time series of SPI, monthly inflow anomaly $\left(\mathrm{Q}_{\text {anomal }}\right)$ and reservoir storage of Furnas HEP.

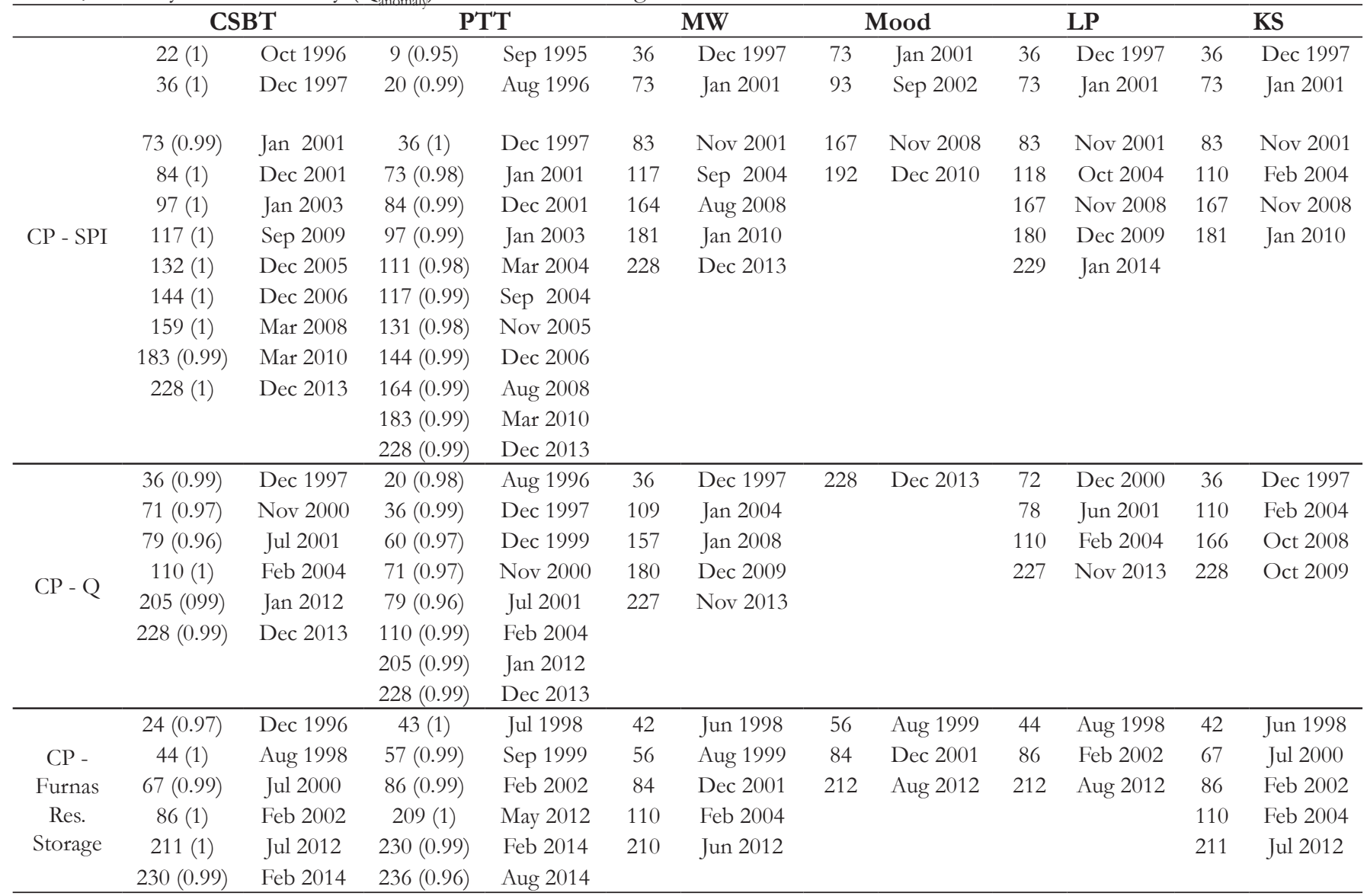

CSBT = Cumulative Sums + Bootstrap; PTT = Pettitt; MW = Mann-Whiteny; LP = Lepage; KS = Kolmogorov-Smirnov. 

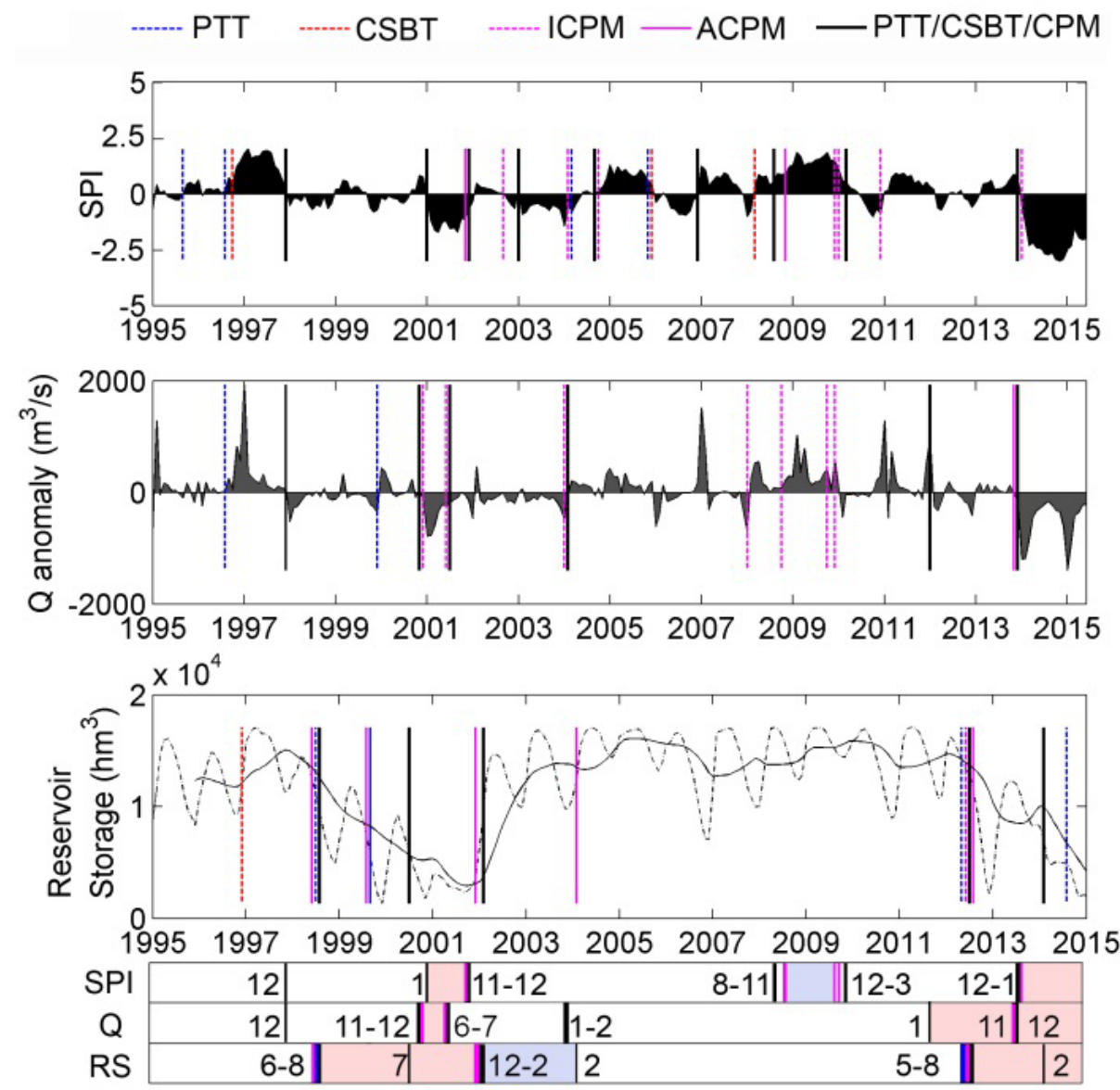

Figure 4. Detected change points (CPs) in SPI and reservoir storage of the equivalent system (RESS). The CPs selected for analysis are featured in the horizontal bar in the center; it shows the months when the changes occurred (Jan-1, Feb-2, ..., Dec-12). Dashed lines represent the CPs from Pettitt (PTT) and CUSUM+Bootstrap (CSBT) methods; and individual tests from CPM package (ICPM). Solid lines represent the CPs detected by all methods in CPM package (ACPM) or at least two out of the three used approaches (PTT, CSBT or CPM).

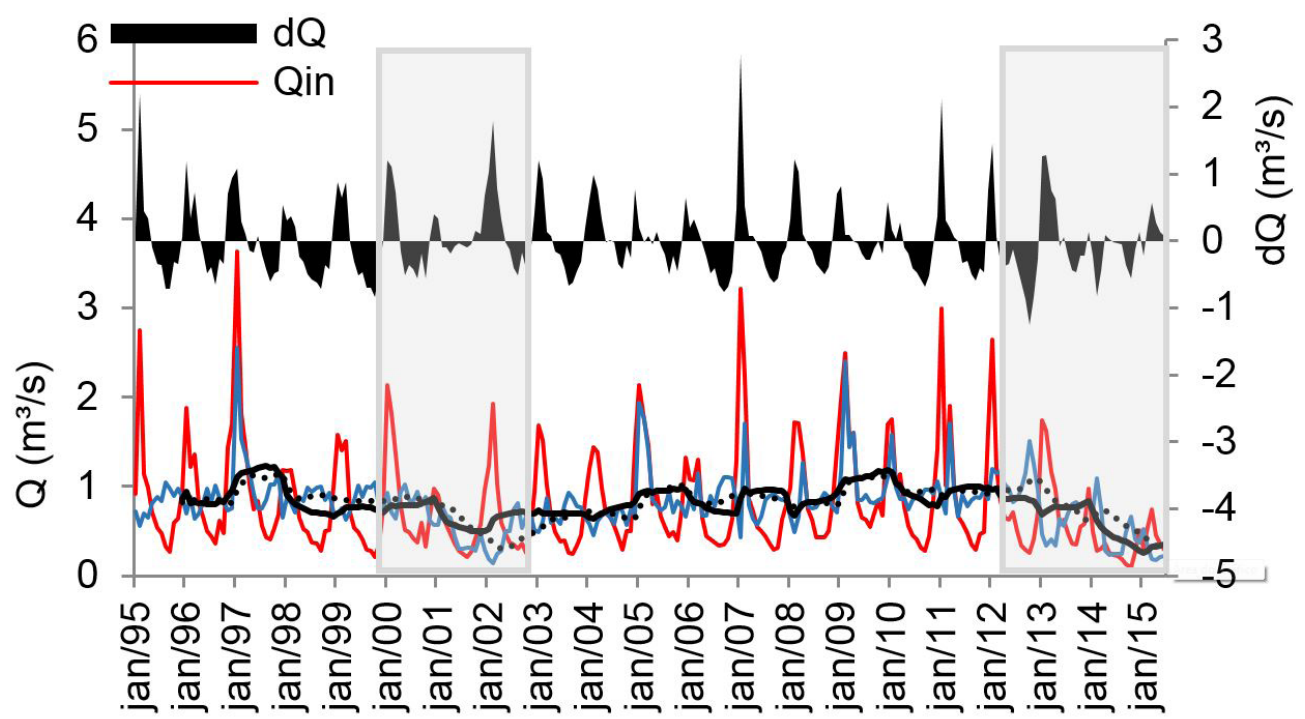

Figure 5. Time series of inflow and outflow at Furnas reservoir; dQ (right axe) is the residual, given by Qin - Qout. The solid and dotted black lines are the moving average of Qin and Qout, respectively. The periods with grey bands are discusses in detail in the text. 
for electric energy, especially since 2010 (Figure 3), may have demanded more hydroelectric generation in 2012 from Furnas HEP. Significant changes in SPI and Q occurred in Dec 2013, which were followed by another change in reservoir storage after 1-2 months.

In both droughts (early 2000s and 2014), the previous decline of reservoir levels occurred because the hydrological responses in this reservoir are controlled by both natural and anthropogenic forcing factors. However, the balance between these two forcing factors may vary in time. Inflow $\left(\mathrm{Q}_{\mathrm{in}}\right)$ and outflow $\left(\mathrm{Q}_{\text {out }}\right)$ time series from Furnas reservoir indicate that, in general, $Q_{i n}>Q_{o u t}$ in the rainy season and $Q_{\text {out }}>Q_{i n}$ in the dry season (Figure 5). During a drought, the electricity generation balances with the need to maintain the minimum outflow, regulated by the Electric System National Operator (ONS - Operador Nacional do Sistema Elétrico), and to minimize storage loss.

$\mathrm{Q}_{\text {out }}$ data indicate that HEG was reduced in 2001 (grey bands in Figure 5), with $\mathrm{Q}_{\text {in }} \cong \mathrm{Q}_{\text {out }}$ during the dry season. As a result, the positive and negative residual $\mathrm{dQ}\left(\mathrm{Q}_{\text {in }}-\mathrm{Q}_{\text {out }}\right)$ converged to zero. In the following drought, dQ was mostly negative between mid-2013 through late 2014 although the absolute values of $\mathrm{Q}_{\text {out }}$ were similar to that in early 2000: the lowest value of the moving average of $\mathrm{Q}_{\text {out }}$ between 2000 and 2003 was $\sim 0.5 \mathrm{~m}^{3} / \mathrm{s}$. On the other hand, the decrease of $\mathrm{Q}_{\text {in }}$ was more critical during the 2014 dry period than in the early 2000s: the moving average of $\mathrm{Q}_{\text {in }}$ was $\sim 0.35 \mathrm{~m}^{3} / \mathrm{s}$ in Jan 2015 , representing a reduction of $\sim 30 \%$ relative to that in Jan $2002\left(\sim 0.5 \mathrm{~m}^{3} / \mathrm{s}\right)$.

Based on that analysis and supported by SPI (Figure 4), it is reasonable to deduce that the hydrological impacts of the 2014 drought in this basin were greater than that in the early 2000s. Why, then, similar depletion of FR is observed during both periods? Note that, between Jan 1998 and late 2000 ( 3 years), the accumulated residual (dQ) is negative, as the moving average of $Q_{\text {out }}>Q_{\text {in }}$. This is basically the same period during which reservoir storage declined and change points were identified (Figure 4). Conversely, before the severe to extreme dry period (SPI -2.5) in 2014, the period with negative accumulated residual last $\sim 1.5$ year (Jan 2012 to $\sim$ Jun 2013, grey bands in Figure 5).

Additionally, $\mathrm{Q}_{\text {out }}$ records suggest that the hydroelectric generation in Furnas HEP was reduced throughout the year of 2001. At that same period, a moderate to severe dry condition (SPI $\sim-1.5$ ) established in the basin (Figures 3 and 4). On the other hand, moving average of $\mathrm{Q}_{\text {out }}$ experienced a reduction in early 2013, 1 year before the onset of the 2014 drought. Thus, a lower HEG in 2001 likely resulted in a less critical depletion of Furnas reservoir whereas such "strategy" was not enough in $2013 / 2014$ as the rainfall deficits in this basin were much more critical than in the early 2000s drought (Figure 4).

\section{Sensitivity analysis}

The results in the previous section expose the uncertainty of the selected approaches for change point detection as they do not always identify the same CPs. Indeed, there are several methods for detecting change points in time series and is unlikely that the detected changes will be the same in all of them. To illustrate that fact, RESS data were used to perform several runs with the
$\mathrm{R}$ package 'CPM', varying the parameter $\mathrm{ARL}_{0}$ and fixing the parameter 'startup' to the minimum value allowed by the package (20). The number of detected points is expected to decrease as $\mathrm{ARL}_{0}$ increase.

In general, the decrease of detected change points occurs for $1000<\mathrm{ARL}_{0}<3000$ and $\mathrm{ARL}_{0}>10000$. Figure 6 shows that the Mann-Whitney (MW) and Kolmogorov-Smirnov (KS) tests are the less sensitive: the number of detected change points drops from 9 to 5 (MW) for the total range of $\mathrm{ARL}_{0}$ whereas, using Mood, there is a drop from 8 to only 1 change point.

It can also be noted that setting the same value of $\mathrm{ARL}_{0}$ for all four methods results in different number of CPs. For $\mathrm{ARL}_{0}=19000$, six CPs were detected using Mann-Whitney (MW) and Lepage (LP) tests whereas only one CP was detected using Mood test. Conversely, for $\mathrm{ARL}_{0}=2000$ the number of detected CPs ranged from five $(\mathrm{KS})$ to eight points. This analysis shows the importance concerning the choice of $\mathrm{ARL}_{0}$ in reducing the divergence among results from different tests, which makes the user more confident about the detected CPs.
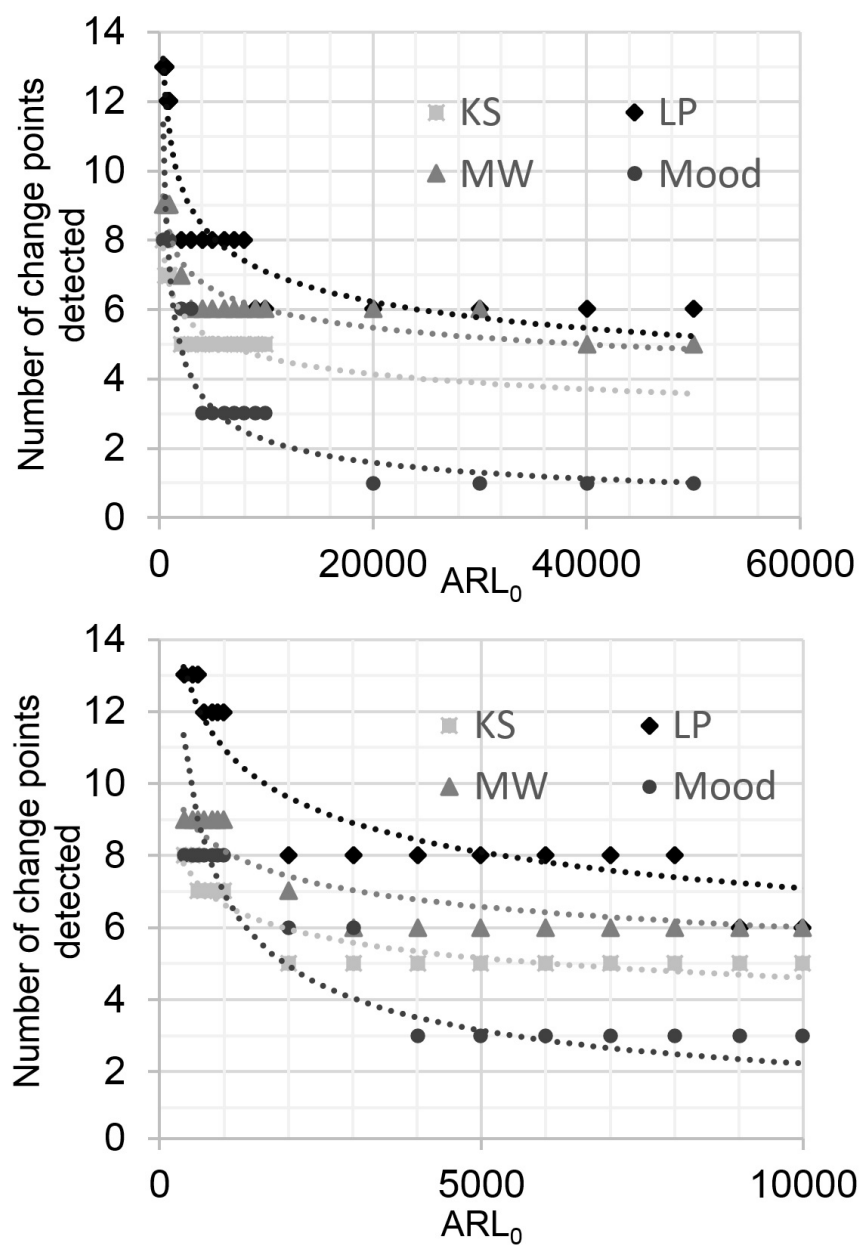

Figure 6. Sensitivity analysis of the CPM package to changes in the parameter ARL0 for change point detection based on four test statistics: Kolmogorov-Smirnov (KS), Lepage (LP), MannWhitney (MW) and Mood. Both figures show the same results but with different ranges in the $\mathrm{x}$-axis. 


\section{CONCLUSION}

In this study, six test statistics were applied to monthly time series of reservoir storage, river discharge and SPI to detect significant change points in the average behavior.

Based on change point (CP) analysis, it can be concluded that the time lag between meteorological shifts and total reservoir storage of 32 reservoirs (RESS) in the Paraná basin varies from 0 to 6 months. There is strong evidence that RESS was more sensitive to meteorological forcing in the 2014 drought than it was in the early 2000s drought. CP analysis using Furnas reservoir (FR) storage and discharge (Q) data, and SPI relative to the contributing basin of FR indicated that the time lag between changes in SPI and $\mathrm{Q}$ is less than one month. Similar to the behavior reported regarding RESS, response time between meteorological forcing and changes in FR storage was shorter in the 2014 drought compared to the early 2000 s drought.

Analysis of SPI, FR storage and balance between inflow and outflow to/from FR revealed that, although similar decline in the lake levels were registered, the depletion during the early 2000s drought was most likely caused by anthropogenic forcing, i.e., dam operation; whereas the meteorological forcing had a major role in determining the storage depletion in 2013/2014.

Results from the CP analysis suggested different responses depending on the method and parameter setup. For example, a sensitive analysis of the R package 'CPM' showed that the test statistics Mann-Whitney and Kolmogorov-Smirnoff are less sensitive than the Lepage and Mood methods. Thus, it is recommended that the identification of change points in hydrological time series should be a supervised process and that multiple approaches should be used. That should allow the user to identify limitations of each method. It is worth mentioning that the CP analysis intends to specify the exact point where a change occurred in a time interval whereas visual inspection can only capture the existence of such change.

The presented results show that storage variation in reservoirs is controlled by a balance between meteorological forcing and human controls. Such balance is particularly important for determining the impacts of droughts on hydroelectricity generation and water supply, especially in Brazil, given that $\sim 70 \%$ of electricity in the country is from hydroelectric power plants (HEP). Thus, quantifying linkages between meteorological forcing and hydrological responses is critical for water resources management and hydroelectricity generation planning.

\section{ACKNOWLEDGEMENTS}

This study was supported by the National Council for Scientific and Technological Development (CNPq - Conselho Nacional de Desenvolvimento Científico e Tecnológico), grant numbers 206857/2014-4 and 142252/2013-1).

\section{REFERENCES}

ANA - AGÊNCIA NACIONAL DE ÁGUAS. Atlas Brasil: abastecimento urbano de água: panorama nacional. Brasília, 2010.

BARKER, L. J.; HANNAFORD, J.; CHIVERTON, A.; SVENSSON, C. From meteorological to hydrological drought using standardised indicators. Hydrology and Earth System Sciences Discussions, v. 12, n. 1, p. 2827-2875, 2015.

EFRON, B. Bootstrap methods: another look at the jackknife. Annals of Statistics, v. 7, n. 1, p. 1-26, 1979. http://dx.doi.org/10.1214/ aos/1176344552.

FIORILLO, F.; GUADAGNO, F. M. Karst spring discharges analysis in relation to drought periods using the SPI. Water Resources Management, v. 24, n. 9, p. 1867-1884, 2009. http://dx.doi. org/10.1007/s11269-009-9528-9.

GAO, P.; MU, X.-M.; WANG, F.; LI, R. Changes in streamflow and sediment discharge and the response to human activities in the middle reaches of the Yellow River. Hydrology and Earth System Sciences, v. 15, n. 1, p. 1-10, 2011. http://dx.doi.org/10.5194/ hess-15-1-2011.

GOCIC, M.; TRAJKOVIC, S. Analysis of changes in meteorological variables using Mann-Kendall and Sen's slope estimator statistical tests in Serbia. Global and Planetary Change, v. 100, p. 172-182, 2013. http://dx.doi.org/10.1016/j.gloplacha.2012.10.014.

HUFFMAN, G. J.; BOLVIN, D. T.; NELKIN, E. J.; WOLFF, D. B.; ADLER, R. F.; GU, G.; HONG, Y.; BOWMAN, K. P.; STOCKER, E. F.. The TRMM multi-satellite precipitation analysis: quasi-global, multi-year, combined-sensor precipitation estimates at fine scale. Journal of Hydrometeorology, v. 8, n. 1, p. 38-55, 2007. http://dx.doi.org/10.1175/JHM560.1.

IBGE - INSTITUTO BRASILEIRO DE GEOGRAFIA E ESTATÍSTICA. Contas regionais do Brasil. Rio de Janeiro, 2014.

LAVIELLE, M. Detection of multiple changes in a sequence of dependent variables. Stochastic Processes and Their Applications, v. 83, n. 1, p. 79-102, 1999. http://dx.doi.org/10.1016/S03044149(99)00023-X.

LEBLANC, M. J.; TREGONING, P.; RAMILLIEN, G.; TWEED, S. O.; FAKES, A. Basin-scale, integrated observations of the early 21 st century multiyear drought in southeast Australia. Water Resources Research, v. 45, n. 4, p. 1-10, 2009. http://dx.doi. org/10.1029/2008WR007333.

LOBEL, F.; MAIA, D.; SOARES, M.; LEITE, M. Drought in Southeast Brazil Hits 133 cities with consequences for the economy. Folha de S. Paulo, São Paulo, 11 mar. 2014. Available from: < http:// www1.folha.uol.com.br/internacional/en/brazil/2014/11/1542425drought-in-southeast-brazil-hits-133-cities-with-consequencesfor-the-economy.shtml>. Access on: 6 jan. 2016.

MCKEE, T. B.; DOESKEN, N. J.; KLEIST, J. Drought monitoring with multiple time scales. In: AMS CONFERENCE ON APPLIED CLIMATOLOGY, 9., 1993, Dallas. Proceedings... Dallas: American Meteor Society, 1993. p. 233-236.

NASA - NATIONAL AERONAUTICS AND SPACE ADMINISTRATION. Tropical Rainfall Measuring Mission TRMM. Senior review proposal. Washington, 2011. 
ONS - OPERADOR NACIONAL DO SISTEMA ELÉTRICO. Histórico de operação. Brasília, 2015. Available from: <http:/ / www.ons. org.br/historico/geracao_energia.aspx>. Access on: 13 jun. 2016.

PETTITT, A. N. A non-parametric approach to the change-point problem. Journal of the Royal Statistical Society. Series C, Applied Statistics, v. 28, p. 126-135, 1979.

RADZIEJEWSKI, M.; BARDOSSY, A.; KUNDZEWICZ, Z. W. Detection of change in river flow using phase randomization. Hydrological Sciences Journal, v. 45, n. 4, p. 547-558, 2000. http:// dx.doi.org/10.1080/02626660009492356.

ROSA, L. P.; LOMARDO, L. L. B. The Brazilian energy crisis and a study to support building efficiency legislation. Energy and Building, v. 36, n. 2, p. 89-95, 2004. http://dx.doi.org/10.1016/j. enbuild.2003.09.001.

ROSS, G. J. Package 'c $p m$ ': sequential and batch change detection using parametric and nonparametric methods. [S.l.]: [s.n.], 2015. Available from: <https://cran.r-project.org/web/packages/cpm/ cpm.pdf>. Access on: 1 jun. 2016.

ROSS, G. J.; ADAMS, N. M. Two nonparametric control charts for detecting arbitary distribution changes. Journal of Quality Technology, v. 44, p. 102-116, 2012.

ROSS, G. J.; TASOULIS, D. K.; ADAMS, N. M. Nonparametric monitoring of data streams for changes in location and scale. Technometrics, v. 53, n. 4, p. 379-389, 2011. http:/ /dx.doi.org/10.1198/ TECH.2011.10069.

SHARIFZADEH, M.; AZMOODEH, F.; SHAHABI, C. Change detection in time series data using wavelet footprints. In: MEDEIROS, C. B.; EGENHOFER, M.; BERTINO, E. (Eds.). Advances in spatial and temporal databases, lecture notes in computer science. Heidelberg: Springer Berlin, 2005. p. 127-144.

SHI, X.; WANG, X.-S.; WEI, D.; WU, Y. A sequential multiple change-point detection procedure via VIF regression. Computational Statistics, v. 31, n. 2, p. 671-691, 2016. http://dx.doi.org/10.1007/ s00180-015-0587-5.

SZALAI, S.; SZINELL, C. S.; ZOBOKI, J. Drought monitoring in Hungary. In: WILHITE, D. A.; SIVAKUMAR, M. V. K.; WOOD, D. A. (Eds.). Early warning systems for drought preparedness and drought management. Lisboa: World Meteorological Organization, 2000. p. 182-199.

TEODORO, P. E.; CORREA, C. C. G.; TORRES, F. E.; OLIVEIRAJUNIOR, J. F.; SILVA JUNIOR, C. A.; GOIS, G.; DELGADO, R. C. Analysis of the Occurrence of Wet and Drought Periods Using Standardized Precipitation Index in Mato Grosso do Sul State, Brazil. Journal of Agronomy, v. 14, n. 2, p. 80-86, 2015. http:// dx.doi.org/10.3923/ja.2015.80.86.
TIGKAS, D.; VANGELIS, H.; TSAKIRIS, G. Drought and climatic change impact on streamflow in small watersheds. The Science of the Total Environment, v. 440, p. 33-41, 2012. http://dx.doi. org/10.1016/j.scitotenv.2012.08.035. PMid:22963988.

VAN DIJK, A. I. J. M.; BECK, H. E.; CROSBIE, R. S.; DE JEU, R. A. M.; LIU, Y. Y.; PODGER, G. M.; TIMBAL, B.; VINEY, N. R. The Millennium Drought in southeast Australia (2001-2009): natural and human causes and implications for water resources, ecosystems, economy, and society. Water Resources Research, v. 49, n. 2, p. 1040-1057, 2013. http://dx.doi.org/10.1002/wrcr.20123.

VAN LOON, A. F.; VAN HUIJGEVOORT, M. H. J.; VAN LANEN, H. A. J. Evaluation of drought propagation in an ensemble mean of large-scale hydrological models. Hydrology and Earth System Sciences, v. 16, n. 11, p. 4057-4078, 2012. http:/ /dx.doi. org/10.5194/hess-16-4057-2012.

VICENTE-SERRANO, S. M.; LÓPEZ-MORENO, J. I. Hydrological response to different time scales of climatological drought: an evaluation of the Standardized Precipitation Index in a mountainous Mediterranean basin. Hydrology and Earth System Sciences, v. 9, n. 5, p. 523-533, 2005. http://dx.doi.org/10.5194/ hess-9-523-2005.

WANG, W.; ERTSEN, M. W.; SVOBODA, M. D.; HAFEEZ, M.; WANG, W.; ERTSEN, M. W.; SVOBODA, M. D.; HAFEEZ, M. Propagation of drought: from meteorological drought to agricultural and hydrological drought. Advances in Meteorology, v. 2016, p. 1-5, 2016.

WILHITE, D. A.; GLANTZ, M. H. Understanding the drought phenomenon: the role of definitions. Water International, v. 10, n. 3, p. 111-120, 1985. http://dx.doi.org/10.1080/02508068508686328.

WMO - WORLD METEOROLOGICAL ORGANIZATION. Atlas of mortality and economic losses from weather, climate and water extremes (1970-2012). Geneva, 2014.

XAVIER, A. C.; KING, C. W.; SCANLON, B. R. Daily gridded meteorological variables in Brazil (1980-2013). International Journal of Climatology, v. 36, n. 6, p. 2644-2659, 2015. http://dx.doi. org/10.1002/joc. 4518 .

\section{Authors contributions}

Davi de C. D. Melo: Initial conception of the research, testing and data collection, analysis of results and drafting the article.

Edson Wendland: Analysis of results and drafting the article. 